\title{
The Precarity of Peri-urban Resistance: A Resistance to the Forced Eviction of Pasar VI Village and the Development of Kualanamu International Airport, North Sumatera
}

\author{
Iswan Kaputra ${ }^{1}$ and Prathiwi Widyatmi Putri2*
}

Received: 5 January 2020 | Accepted: 28 May 2020 | Published: 12 June 2020

\begin{abstract}
In 1997, Kualanamu was chosen as the site of a new airport in North Sumatra. The central government's unilateral decision created new agrarian conflict and complicated the agrarian issues that had plagued the region since the colonial era. The accumulated conflicts and structural issues left local residents in a precarious state as they became integrated into peri-urban society. This article highlights the complexity of the conflict, the agency-institutional-structural relations that underpin it, and peri-urban resistance within the context of urbanisation and its marginalisation of rural communities.
\end{abstract}

Keywords: peri-urban, eviction, rural-urban problems, resistance, agrarian change, urbanisation

\section{Introduction}

The development of the Kualanamu International Airport resulted in the forced eviction of Pasar VI Village, Kualanamu, Beringin District, Deli Serdang Regency, North Sumatra, approximately 25 kilometres east of Medan. Consequently, the majority of villagers lost their access to resources and their livelihoods. The wall constructed by airport authorities has physically segregated residents, dividing them between those within and those without. Consequently, residents have lost their sense of solidarity, and thus had difficult working collaboratively to address socio-ecological issues as well as mitigate the influence of commercialisation.

This article employs a historicgeographic analysis to examine the structural experiences of the residents of Pasar VI Village, Kualanamu. In this, it relies on an institutional dynamics perspective, viewing institutions as the operational entities that link structures and agencies (Hodgson, 2004; Jessop, 2001; Moulaert et al., 2016). This perspective is useful for understanding the diverse structural

\footnotetext{
${ }^{1}$ Bina Keterampilan Pedesaan/ The Activator for Rural Progress (BITRA Indonesia)

${ }^{2}$ University of Copenhagen, Department of Food and Resource Economics, Global Development Section *Corresponding Author
} 
issues, their historical evolution over the decades (or even centuries), and the institutions involved in the shorter-term reproduction of issues. This institutional perspective offers a broad and flexible analytical framework (see, for instance, Healey, 1999; Ostrom, 2005; van der Heijden, 2011). This article uses the stream of thoughts of institutionalism to address the grand structure of political economy while simultaneously recognizing the relationship between political, cultural, and social structures, thereby avoiding the trap of economic determinism (Bakker et al., 2008; Hadiz, 2004; Jessop, 1996; Lambooy and Moulaert, 1996; Moulaert et al., 2016; Moulaert and Mehmood, 2009). This approach is particularly useful for understanding the extent to which social movements and their agents can erode the pillars of the dominant structures by promoting shorter-term institutional change.

Through this case study, we show how the agrarian transformation has produced institutions and structures that stymie efforts of the inhabitants to claim access to resources and livelihoods. The development of Kualanamu Airport, as well as the forced evictions that accompanied it, cannot simply be reduced to a conflict between PT Angkasa Pura and evicted residents. To understand this case structurally, we position the agrarian conflict within two interrelated structuralhistorical trajectories. First, this case is inexorably related to the agrarian history of Java and Sumatra since the colonial era. The colonial system's control of land and labour created poverty in traditional agrarian communities, with peasants being dispossessed of their land and assets through transmigration, relocation, and the informalisation of the workforce (Alexander \& Alexander, 1991; Elson, 1986;
Stoler, 1986, 1995). Second, this conflict is part of global urbanisation processes (Brenner \& Schmid, 2014; Harvey, 2003, 2012; Ruddick, 2015), which have precipitated the creation of an informal precariat not only in major economic centres but also in smaller cities, townships, and rural/peri-urban communities (Cuevas et al., 2009; Li, 2010).

Popular efforts to guarantee access to resources and to defend the right to housing and livelihood have often been stifled, particularly in the face of deeprooted structures and institutions. They face such obstacles as pro-market and prourbanisation development processes, ineffective democratic systems that are incapable of representing popular aspirations; as well as financial constraints that limit popular organisational and oppositional capacity.

This article departs from lengthy experience in the field. Especially, the first author, working in conjunction with BITRA Indonesia, spent more than ten years actively organising, guiding, and advocating for the residents of Pasar $\mathrm{VI}$ Kualanamu. BITRA Indonesia employed a participation action research (PAR) to help villagers campaign for the fulfilment of their fundamental right to be relocated to a new settlement with sufficient fertile land for subsistence farming. This article is divided into six sections, each of which employs a specific conceptual framework to analyse data collected in the field. After this introduction, the second section discusses agrarian transformation and urbanisation using an institutional dynamics approach. The third section presents our reading of the impovertisation of Kualanamu and its transformation into a peri-urban village. In the fourth section, we present the context of the Kualanamu 
International Airport and the structural persistence of dispossession. The fifth section narrates the process through which the people of Kualanamu became agents who actively campaigned against forced eviction and the violation of their rights. The sixth section summarises the ruralurban issues and draws a general conclusion regarding the precarity of rural and peri-urban resistance within the context of urbanisation and globalisation.

\section{Understanding Agrarian Transformation: Historical and Geographic Factors from An Institutional Dynamics Perspective}

Social relations have long been conceptualised through analysis of the interactions between individuals and collective entities known as society. The concepts of agency, i.e. individuals who actively undertake action to influence their social environments, and structure, i.e. transformative entities that operate beyond the influences of individuals and groups, are not free from ontological, epistemological, and methodological problems (see Hodgson, 2004; Jessop, 2005; Moulaert and Mehmood, 2009). From a critical realist perspective, reality consists of layered structures (social, natural, e.g. biological and physical worlds) with different influential potential; each the structural layers has its own emergent properties that are evident in specific times and spaces. These layers are relatively stable and independent, but nonetheless mutually influential (Hodgson, 2004; Jessop, 2005). The relationships between structures and agencies are not mechanic, regular, or predictable. Similarly, they are not unilateral; structures, for example, do not fully determine the actions of agents, and agents' actions cannot wholly transform structures and their mechanisms (Hodgson, 2004). Not to weigh only to one dimension of the relationship, whether agencies or the structure solely directing the social relations and transform the other, a framework that allows adequate explanation for both structural and individual transformation is needed (Hodgson, 2004).

The analytical components of institutions and institutional dynamics provide a more comprehensive understanding of the mutual relationship between agencies (also known as actors) and structures (for surveys, see Jessop, 2005; Moulaert \& Mehmood, 2009). Within academic traditions that depart from micro analysis, expanding from the community level to the urban and national levels, institutionalism offers an understanding of social interactions with the following, but not only, fundamental premises: 1) structural issues affect some individuals and groups more significantly than others; in other words, different individuals and groups experience structural issues (capitalism, militarism, feudalism, gender bias, etc.) through different processes and with different effects; 2) different individuals and groups have different capacities to deal with structural transformations as they are influenced by different institutional settings (i.e. social welfare, healthcare, education, law, traditions, etc.); 3) individuals may stabilise, challenge, or even dismantle existing systems through collective agreements, socio-political contracts, and new norms, and over time this may create new institutions with structural impacts that can affect individual and collective behaviour.

In this article, we focus on how the agrarian structure has adopted its current 
format under the influence of global urbanisation as well as how agents (victims of forced eviction and their allies) created the momentum necessary to oppose to development of an international airport. The processes of agrarian transformation, urbanisation, and industrialisation are far from uniform, being influenced by market and non-market mechanisms as well as state and civil institutions that emerged within specific economic, social, and political contexts (Byres, 2016; McMichael, 1997; Mingione, 1991; Swyngedouw, 2004). Indonesia and other nations in the Global South have had different experiences than western industrialised countries, and as such their situations cannot be readily explained by the theories that are commonly used in Europe and North America (see Hadiz \& Robison, 2005; Li, 2010; Watts, 1989).

We do not intend to formulate a new theory of social transformation to analyse the specific case of Indonesia. Rather, we will discuss a specific case that reflects one characteristic of the Global South that has been rarely discussed: the complex aggregate of both the agrarian problem and the urban problem, which used to be addressed separately within different scholarly traditions. This approach is particularly useful for understanding the perpetuation of poverty amongst periurban poor communities through sustained processes of dispossession. In such communities, post-colonial agrarian transformations have intersected with accelerated global urbanisation to create conflict (the emergent properties) within a new spatial entity, what we term the periurban village. Such structural issues have also stimulated new patterns of resistance, which have unfortunately been smaller and more sporadic than the former traditions of social movements that were concentrated in rural or urban areas.

\section{The Impovertisation of the Rural and the Creation of the Peri-urban}

Pasar VI Village, Kualanamu, was created as a result of transmigration. Initially, residents' economic and social relations were predominantly informed by labour-contract in tobacco plantation industries, social isolation, and a subsistence agricultural system used by the poor residents of Deli. This colonial-era impovertisation continued to shape postindependence communities as various marginalising socio-economic institutions keep being reproduced. This section discusses several of the institutions that have been involved in Kualanamu's historic and geographic development. Although this discussion is presented chronologically, this does not mean that institutions' emergence and development have been linear; indeed, in the contemporary era they operate simultaneously.

The Expansion of Plantations and Informalisation of Employment

The passage of the Agrarian Law (Agrarische Wat) in 1870 marked a new era of Dutch colonialism in the Indonesian archipelago, as this law stipulated that all land should be used to promote the colonial economy and provided legal protection to the plantation sector (Siyo et al., 2008, pp.72-74). When small-scale plantations were destabilised by an economic crisis in the mid-1880s, large corporations began consolidating their capital and taking control of these plantations' assets. Ultimately, between the 1890s and the 1930s, numerous 
onderneming (large plantations) were opened by European. American, and Japanese corporations, being used to cultivate tobacco, rubber, tea, and oil palms (Stoler, 1995, pp.16-21).

These plantations were made possible by the land concession system, which primarily benefited private-sector actors with erfpacht rights. ${ }^{3}$ Under this system, land concessions were granted for a period of 75 years, with the option to extend the concession for fifty years if necessary. In return, private-sector actors were required to pay cijns (feudal taxes) of one rupiah per hectare per annum to the Sultan of Deli; this amount could be reduced if deemed necessary. ${ }^{4}$
When tobacco plantations proved capable of producing quality leaves, new plantations were opened in East Sumatra, or Deli (now North Sumatra). Other privatesector actors began cultivating rubber and oil palms. The following table summarises the data presented by Kasimo during a 1953 congress of the Parliament of the United States of Indonesia. In the colonial era, East Sumatra had covered an area of $3,031,000$ hectares (significantly smaller than modern-day North Sumatra, which covers an area of $7,298,100$ hectares). Of this land, almost $30 \%-888,000$ hectareswas being cultivated by foreign corporations; less than $10 \%$ of this land was being used for subsistence farming by local residents.

Table 1. Land Usage Before Independence

\begin{tabular}{clccc}
\hline No & \multicolumn{1}{c}{ Type of Land } & Area & Sub-Area & $\%$ \\
\hline 1. & Forest & $1,891,000$ & & 62.4 \\
& a. Reserve forest & & 519,000 & \\
& b. Jungle & & $1,372,000$ & \\
2. & Concession land & 888,000 & & 29.3 \\
& a. Tobacco & & 261,000 & \\
& b. Planted perennials & & 394,000 & \\
& c. Unplanted perennials & & 233,000 & \\
3. Subsistence farming & 252,000 & & $8.3 \%$
\end{tabular}

${ }^{3}$ One of the largest and earliest concession holders, or erfpacht, was NV Deli Maaschappij $(120,000$ ha), which was established by Jacob Nienhuys and Peter Wilhelm Janssen in 1869 in Deli, East Sumatra. In 1889, NV Deli Maaschappij acquired stock in the firm Naeher \& Grob, rebranded itself as NV Senembah Maaschappij, and expanded its plantation past the Serdang River.

${ }^{4}$ Concessions were provided by the sultan, who also provided the necessary documents and agreements. Such concessions also included rural villages, with residents whose rights had to be protected; this meant that, in practice, the sultan entrusted the fates of the common people to the onderneming. Initially, each region had its own regulations; standardisation only occurred once the government became involved. Concessions were provided for a maximum of 75 years, with the potential of extending the concession for another fifty years. For each hectare of land, a cijns (feudal tax) of Rp 1.00 had to be paid every year; this amount could be reduced if necessary. 

a. Rubber
60,000
b. Coffee
500
c. Coconut
15,000
d. Sugar Palm
500
e. Fruit
7,000
f. Irrigated rice
19,000
g. Non-irrigated rice
28,000
h. Vegetables and tobacco
2,000
i. Other/mixed
120,000

Total

$3,031,000$

100

Source: Compiled by first author from Kusbianto (2016).

Formal institutions affected the social structure through their regulation of land use and their practices of dispossession and informalisation. This informalisation reproduced subsistence production mechanisms, and as such could not create a proletariat-a class of labourers who rely on their wages for survival. It was perpetuated not through a failure to create consolidation, but because of political considerations. Plantations deliberately maintained the peasant class, which was subjugated by bureaucrats, thugs, and brokers with a specific interest in maintaining the existing system (compare Akram-Lodhi and Kay, 2010a, 2010b).

As new lands were opened for tobacco farming in East Sumatra, demand increased for workers (koeli) ${ }^{5}$ who could be cheaply employed and easily controlled. These workers were imported from Java, having been deceived by the promises of great wealth and glorious opportunities in a land where money grew on trees (referring to the tobacco leaves that were sold at high

5 The term koeli is thought to have originated
from the English-language term coolie, which prices in Europe), (Aulia, 2006). The first migrant workers-150 farmers from Bagelan, Purworejo, Central Java-arrived in Deli in 1880. The flow of labour continued, with workers coming not only from Java but also China and India. By 1905, Deli was home to 33,961 Javanese koeli, including 6,290 women (Breman, 1997, p. 67).

Before migrating to Sumatra, these Javanese workers had lived in great poverty. Many experienced malnutrition and even famine owing to their lack of land; the colonial government had used most arable land to cultivate cash crops such as sugar, coffee, tobacco, tea, rubber, quinine, and coconuts. These precarious peasants-blinded by the promise of a better future-found only new tragedy when they migrated to Deli. In their new homes, these migrants faced deplorable conditions, low wages, and violence at the hands of their foremen and the foreign plantation owners. Women workers were even more vulnerable, being subjugated

itself is derived from the Tamil kuli (the wage paid to manual labourers). 
through sexual abuse, forced marriage, and domestic slavery (Stoler, 1986, pp. 31-35).

As a means of controlling workers, companies forced their employees to live in barracks. Contracts were far from just, being short-term and offering no legal protection (see Stoler, 1986). Workers' wages were only sufficient for survival, and even this was not guaranteed; malaria and cholera were endemic. Arguing, fighting, and even killing were all part of workers' everyday lives (see Stoler, 1992; Stoler, 1995).

Plantation owners and administrators, popularly known as Toean Keboen, manipulated their workers into signing new contracts every three years. Shortly before the end of the current contract, plantation owners would sponsor performances of Javanese art as a means of taking workers' wages and savings. Shortly before these performances, the Toean Kebun and their associates would visit the barracks and offer loans. This mechanism was used to systematically impoverish workers, thereby ensuring that workers would extend their contracts rather than use their savings to return to Java. To this day, such stories continue to be shared and transmitted amongst local residents.

In 1891, there were 169 plantations in Deli (Schadee, 1919, p. 191), and at the dawn of the 20th century, an average of 7,000 Javanese workers were being brought to East Sumatra every year (Breman, 1997, p. 68; Sihaloho, 2004, p. 430). The number of Javanese in East Sumatra $(353,551)$ surpassed the number of Malays $(285,553)$ in 1920 . When World War II broke out, $60 \%$ of East Sumatra's

6 Contrast with the 1930 census (as cited by Stoler, 1986, p. 35), which identifies the region as home to $1,500,000$ Javanese, residents were Javanese (Sihaloho, 2004, p. 430). These figures include not only the Javanese working on the plantations-in 1926, East Sumatra was home to 142,000 male workers and 52,400 female workersbut also those who were forced by their circumstances to remain in Sumatra. ${ }^{6}$

In the 1930s, the Great Depression forced the closure of numerous plantations in East Sumatra (Breman, 1997, p. 1). This resulted in the firing of numerous workers. Some chose to return to Java, but the majority decided to remain in East Sumatra. The 1930 census in East Sumatra (as cited by Stoler, 1986, p. 35 ) identified $1,500,000$ Javanese in the region, with more than half of them living outside plantations. A few established informal communities in trade centres such as Medan, Pematang Siantar, Tebing Tinggi, and Kisaran, but most established underground settlements around the plantations, existing outside the authority of the colonial government and the Malay Sultanate (Stoler, 1986, p. 36). The peri-urban villages around the Kualanamu International Airport grew from such settlements.

In short, the large plantations and their workforce management created new institutions that contributed to the creation of peri-urban communities and the precariat inhabiting them. Historical conditions, including plantations' dependence on informal labour, lack of commitment to workers' welfare, and their desire to create a modern industry, shaped the everyday social relations of rural communities. Ultimately, these institutions reached past the plantation industry, informing villages' built environments and

more than half of whom lived outside of plantations. 
their use of space, land, and natural resources. Such institutions, thus, were not shaped solely by specific local conditions, but also by broader trends in migration and spatial production (Leaf, 2002; Narain, 2009).

\section{Creating Peri-urban Villages through Four Waves of Post-Independence Migration}

The first wave of migration from Java occurred in the colonial era, as discussed above. Migration continued after Indonesia's independence, increasing when the country experienced food insecurity under the Old Order regime. Such migration was formalised by the New Order government through its transmigration program, which it intended as a means of avoiding overpopulation in Java and improving development in Sumatra. ${ }^{7}$ This may be identified as the second wave of migration. The third wave occurred in the 1980s, and involved white-collar workers and university students who sought employment and knowledge in Sumatra. Rapid industrial growth has made North Sumatra a magnet for entrepreneurs seeking to establish service companies and merchants desiring new trading opportunities; this may be categorised as the fourth wave. Through these waves of migration, peri-urban villages such as Pasar VI Kualanamu, grew rapidly.

Unlike villages that had been established informally, Pasar VI Kualanamu had been founded on land owned by NV Senembah Maaschappij (later renamed PT Perkebunan Nusantara II, or PTPN II, after

${ }^{7}$ Quoting Mohammad Hatta in the Economic Forum Meeting (3 February 1946) as cited in Ministry of Villages, Development of being nationalised in the 1950s). Villagers were descended from the Javanese labourers who had travelled to North Sumatra during the first and second waves of migration.

The village's name, "Pasar VI", traces its roots to historical plantation activities. In the local language, the word pasar means path, and is used to refer to the footpaths used by workers to collect crops (tobacco, rubber, oil palms, etc.) These pasar were numbered based on their position relative to the plantation's main office. "Pasar I" was the path closest to the office, while "Pasar XI" was located at the very edge of the plantation. Over time, as plantations grew, they were divided further, with each division given its own name (for example, "Kwala Namu").

The Javanese villages established within and without plantations share several characteristics. These villages tend to be more densely populated than those established by indigenous populations. Houses and other structures are built close to the ground, rather than on stilts. Families do not rely on one source of income, but earn money through several means, as the main source of income-plantation workcannot provide for families' needs. Traditionally, houses have had their own plots of land for growing their own food. As villages have become more urbanised, trade and services have contributed further to families' incomes, with many residents acting as seasonal workers. For families in Javanese villages such as Pasar VI Kualanamu, subsistence agriculture remains necessary for survival.

Disadvantaged Regions, and Transmigration R. I (2015). 
This economic structure has remained relatively stable even as political systems have transformed. Residents of colonial East Sumatra often experienced famine as the most fertile land was being used for cash crops (Stoler, 1986, p. 41). In the colonial era, subsistence farming had to be done furtively, as this was prohibited by the plantation companies, which were unwilling to allocate land for cultivating foodstuffs. Conversely, the Japanese occupation government not only allowed such farming, but required it (Stoler, 1986, pp. 95-102). Populist policies in postindependence Indonesia continued promoting public access to land, particularly after the Sukarno government passed the Basic Agrarian Law (UUPA) and initiated land reform (See Rachman, 2012). As farmers' unions grew, villagers were able to enjoy the fruits of its struggle: the formalisation of employment and the usage of plantation land for public needs. As the availability of land increased, subsistence farming became increasingly prevalent.

This situation reversed after 1965, when villagers' occupation and use of land was staunchly opposed by companies and the state (including the military). The agriculture sector again became informalised, with workers signing shortterm contracts and receiving low wages (Stoler, 1986, pp. 168-172). However, to reduce potential conflict, workers with families were provided with accommodations for the duration of their employment. Families were provided with wood panel houses measuring six-by-six metres and 1,000 square metres of land, upon which they could cultivate additional foodstuffs to support their families (Kaputra et al., 2015, p. 79). Workers grew rice in nearby swamplands, and planted corn, vegetables, and beans in dry lands. In the waterways around their villages, residents sought fish to ensure their protein needs were met; where possible, they would also hunt animals. It may thus be summarised that, under the New Order government, the agrarian system was one of massive monoculture plantations, with a population that was larger than workplace demand. The dominant political structure sought to maintain this surplus population as a means of ensuring economic growth (Li, 2010). This situation perpetuated low wages and informal labour (Bhalla, 2017).

At the grassroots level, villagers created various survival mechanisms within spaces that were not formally controlled by the existing infrastructure; in other words, they seized the opportunities that had been created by gaps between the policies of different regimes. The spatial structure of peri-urban villages remained shaped by the informal economic landscape, which offered access to microlevel production, trade, and service activities while still leaving villagers in a precarious situation (see also Akram-Lodhi \& Kay, 2010b). This precarity was rooted primarily in the instability of the 'commodity' produced by villagers and in villagers' reliance on dominant economic institutions (i.e. plantations) and political systems.

\section{The Development of Kualanamu International Airport and the Structural Persistence of Dispossession}

In this section, we will discuss how agrarian transformations have created a new situation in which dispossession not only affects agricultural communities, but also those that rely on informal or mixed economic systems. Citizens lose their access to informal production 
mechanisms, especially those that facilitate subsistence farming. Peri-urban villages, once shaped predominantly by the plantation system, became diversified with the construction of an international airport.

The Kualanamu Airport was constructed approximately 25 kilometres east of Medan, taking land from the villages of Beringin and Kualanamu, in Beringin District, Deli Serdang Regency, North Sumatra. ${ }^{8}$ Planning for this project began in 1994, following the passage of Presidential Decree No. 76 of 1994 regarding the Establishment of the Committee for Relocating the Polonia Airport, Medan. The state-owned enterprise PT Angkasa Pura II subsequently signed a memorandum of understanding with PT Citra Lamtoro Gung Persada (a company owned by Siti Hardiyanti Indra Rukmana, the daughter of President Soeharto). However, after Indonesia was struck by the Southeast Asian Economic Crisis in 1997, this project was delayed. Construction only began in 2007, with the Kualanamu International Airport being part of the Soesilo Bambang Yudhoyono (SBY) government's Masterplan for Accelerating and Expanding Indonesia's Economic Growth (MP3EI). Pursuant to this master plan, the government sought to improve the North Sumatran economy by facilitating the transportation of people and goods. The intent to promote economic growth resonated with the desire to improve available infrastructure. North Sumatra already had an airport, Polonia, but it was significantly over capacity; in 2012, for

8 The official website of the Department of Transportation (http://dephub.go.id) does not identify Kualanamu Village/Sub-District as the location whereupon the Kualanamu Airport was constructed, even though the name of the example, the number of passengers exceeded the airport's capacity by $800 \%$ (Grahadyarini, 2013).

The construction of new airports tends to involve the massive repurposing of land, and North Sumatra was no exception. The former airport in Polonia was transformed into a shopping centre, with commercial and economic activities being prioritised over the victims of development. According to Batara Taher, who was serving as the Director of the North Sumatran Agriculture Office at the time, the construction of the Kualanamu Airport and supporting facilities necessitated the appropriation of more than 3,000 hectares of productive farmland (Bitra \& Muhammad, 2007). ${ }^{9}$ This compulsory acquisition was mediated by the State, which perceived land as a purely economic asset and failed to consider its sociocultural importance to residents. Ultimately, as common in airport construction in Indonesia (see the cases of the Kertajati Airport, West Java, and the Kulonprogo Airport, Yogyakarta), farmers lost both their livelihoods and a major element of their culture.

In 1997, PT Angkasa Pura II received permission to begin constructing an airport on 1,320 ha of land. The majority of this land $-1,126.77$ ha-had been held by PTPN II under cultivation rights. Of this, 891.3 ha was used for the construction of the airport; the remaining 235.47 ha was located outside the airport walls. For this, Rp 61 billion in compensation was paid to PTPN II, with the expectation that the

airport is taken from this village. (See Pembangunan bandar udara, 2006)

${ }^{9}$ Interview by BITRA Media Syndication with Bintara Taher, Director of the North Sumatra Office of Agriculture.. 
company would address ongoing land issues, including in Pasar VI Village. Conflict and opposition emerged when the company failed to do so, as discussed below.

\section{Occupation, Resistance, and the Struggle for Relocation}

\section{Forced Eviction and Conflict}

After several years of delay, Kualanamu was chosen as the site for the new airport in 1998, with its development plan being approved through Decree of the Minister of Transportation no. 40 of 1998. The tranquillity of Pasar VI Kualanamu was soon disrupted. The developers working on the airport, as well as PTPN II-as the provider of land-used pressure and repression to force residents to abandon Pasar VI Kualanamu. The district chief issued a decree requiring all residents to leave the land, and informal actors ('unknown persons') demolished the elementary school; its staff, meanwhile, were sent to teach elsewhere (Kaputra, 2015 , p. 53). Residents were prohibited from cultivating the land or catching fish, even though construction had not begun. Their access to electricity was severed, and they experienced difficulty accessing public services.

In the contract between PTPN II and PT Angkasa Pura, it is stated that the plantation company was responsible for clearing the land of its occupants, including Pasar VI Kualanamu Village. As compensation, PTPN II offered Rp 2,350,000 to its labourers and Rp 4,292,000 to retired workers. With such a miniscule amount, villagers could not relocate and maintain the same quality of life; it was insufficient to purchase land elsewhere, let alone in an area near the city. Even worse, residents of Pasar VI Kualanamu who were descended from plantation labourers-but who had never worked for the company themselves-were not provided compensation, despite having occupied the land for generations.

Residents of Pasar VI Kualanamu Village firmly rejected the offered compensation. However, their protests and complaints fell on deaf ears. PTPN II, developers, and the district, regency, provincial, and central governments continued development, building walls, inspection roads, security posts, and offices for the project consultant and the project implementation unit (PIU). The construction of the walls resulted in the division of Pasar VI Kualanamu; 71 households (237 individuals) lived within the walls, and refused to move until they were relocated and provided proper relocation, while 97 households lived outside the walls. This physical division had a significant effect on villagers' psyches, solidarity, and harmony. The population, despite sharing kinship bonds, became fragmented. Those living within the walls refused to move, and rejected the construction of the airport, while some of the villagers living outside the walls supported the project. This fragmentation was exacerbated by the divide-and-conquer approach used by developers and their allies (Kaputra, 2015, p. 85).

Even when construction was delayed by the Southeast Asian economic crisis, as mentioned above, forced eviction continued. Construction efforts continued 
in $2002,{ }^{10}$ when the economy had stabilised. Interestingly, while PT Angkasa Pura II provided Rp 1.2 trillion for construction, the majority of funding (USD 225 million) came from foreign loans. Domestic investors were unwilling to fund the project, fearing the potential consequences of Indonesia's ongoing socio-political instability (including widespread protests, which were supported by domestic and international organisations). The link between social movements and socio-political instability was widely debated, as was the need for foreign loans. It was clear, however, that villagers were seeking to maintain their own quality of life and defend their rights. Several of the strategies used by villagers in Pasar VI Kualanamu Village are discussed below.

\section{Public Efforts to Deal with Conflict}

Recognising their weak bargaining position, the villagers who were opposed to the development of the Kualanamu International Airport sought to create solidarity and defend their rights. Supported by several non-governmental organisations (NGOs), primarily the Activators for Rural Progress (Bina Keterampilan Pedesaan, BITRA), activists sought to increase residents' awareness of their rights as citizens. To legitimise their struggle, villagers created their own organisation, the Concord of Weak Peoples (Kerukunan Warga Masyarakat Lemah, KWML). KWML sought to increase its members' intellectual capacity, including their ability to analyse structural conflicts and use participation action research to

${ }^{10}$ Presidential Decree No. 15 of 2002 permits the continued construction of the Kualanamu Airport upon the completion of three studies: identify the causes of their disenfranchisement. In this, they were supported by national and international social movements and social networks. For example, the late George Junus Aditjondro-at the time, a professor at Newcastle University, Australiacontributed to the movement by employing an ethnographic approach to understand and analyse the issues it faced.

Analysis indicates that no fewer than 34 actors, institutions, and organisations had an interest in the airport's construction and were involved in the decision-making process. These included private-sector actors/investors, state-owned enterprises (PTPN II, PT Angkasa Pura, PT Kereta Api Indonesia), security forces (the police and military), youth organisations, the Plantation Workers' Union, local legislators, the central government (including both ministries and the National Land Agency), the regency government, and the district government. Of these, sixteen opposed villagers' demands for relocation, twelve supported the popular movement, and six were neutral, sometimes supporting villagers' efforts and sometimes opposing them ("Strategi Perjuangan KWML Menuju Relokasi \& Distribusi Lahan", prepared in conjunction with Solidarity for Victims of the Development of Kualanamu Airport [SORAKKAN] Coalition, August 2007). Among those supporting popular efforts were politicians from certain parties, national and international NGOs, mass media, members of the North Sumatra Parliament, the SORAKKAN Coalition (consisting of both civil society organisations and student organisations), the National Human Rights Commission,

necessity, funding availability, and special criteria and project characteristics. 
the Supreme Court, and several members of the Indonesian Parliament and the Regional Representation Council. Meanwhile, the Prosecutor General, Ombudsman, Expert Staff of the Vice President, academics, and intellectuals acted neutrally.

Villagers organised themselves through KWML to conduct demonstrations, seek audiences, undertake mediation, and create alliances with political parties, academics, and other civil society organisations from the village level through the national level. Activists also sought to create international solidarity by working with the Asia Pacific Foodfirst Information and Action Network (FIAN), a German food and human rights organisation. After several fact-finding visits, FIAN brought the Kualanamu case to the United Nations' Human Rights Council, the organisation's highest forum for human rights advocacy and protection; Indonesia is one of the council's forty-seven members.

Residents identified their movement as an agrarian political struggle, ${ }^{11}$ one seeking only to ensure that affected families received homes and $2,000 \mathrm{~m}^{2}$ of agricultural land in compensation. ${ }^{12}$ Villagers chose not to use litigation or other legal channels, perceiving the courts as having failed to resolve previous agrarian conflicts in Indonesia and as consistently siding with capital-holders and investors

${ }^{11}$ Urip Santoso (2012, p. 24) defines agrarian politics as involving the body of state policy regarding the use, preservation, exploitation, administration, and distribution of land and natural resources for the betterment of the populace and the state. In Indonesia, agrarian policy must be based in the national philosophy of Pancasila and the Constitution of 1945.
(Sudjono $^{13}$, personal communication, June 9, 2015). Villagers' allies were likewise unwilling to recommend litigation, arguing that a legal approach would only provide a legal basis for subjugating victims. These allies recommended a different approach, one that would benefit villagers and advance their interests.

Four strategies were used to extent the movement's reach ("Strategi Perjuangan KWML Menuju Relokasi \& Distribusi Lahan", KWML - SORAKKAN, August 2007). First, it relied heavily on the mass media for its campaign activities. The case was regularly covered by local and national print and broadcast media. On several occasions, it also drew the attention of international media, such as when FIAN activist Yifang Tang visited Kualanamu when preparing a report about the violation of villagers' food rights for the United Nations.

Second, residents and their allies sought to expand their reach through SORAKKAN (an alliance of residents, NGO activists, and students). This organisation was intended to increase solidarity, improve organisation, and provide guidance through routine discussions and training sessions. SORAKKAN was also intended to improve villagers' awareness, understanding, critical thinking, courage, and skills.

12 This demand has two justifications, namely residents' homes and their cultivated land (a maximum of $2,000 \mathrm{~m}^{2}$ ). During the colonial period, and until nationalisation, workers were generally given money and $2,000 \mathrm{~m}^{2}$ of land upon retirement so that they could continue to cultivate vegetables and other crops in their old age.

${ }^{13}$ Chairman of KWML. 
Third, various advocacy efforts and processes were used to put pressure on developers, including audiences, delegations, demonstrations, and networking with national institutions such as the National Human Rights Commission, the National Parliament, the Ombudsman of Indonesia, the Prosecutor General's Office, the Supreme Court of Indonesia, and the Office of the Vice President of Indonesia.

Fourth, academic research, surveys, and legal reviews were conducted in order to provide a basis for strategy selection and relocation site proposal. Small breakthroughs were made; for instance, the residents of Pasar VI Kualanamu participated in the North Sumatran Development Planning Meeting and urged provincial officials to incorporate the relocation of residents in their development and budgeting activities. At the same time, to improve villagers' economic status, KWML and its allies planted corn and other crops on the contested land.

Activists required a dynamic approach to advocacy, one capable of adapting to their ever-changing situation. They regularly corrected, updated, and revised their concepts, strategies, and approaches. In August 2007, for example, activists documented their revised strategies in a document titled "Strategi Perjuangan KWML Menuju Relokasi \& Distribusi Lahan" and highlighted their ultimate goal: the relocation of residents to a new village and the provision of at least $2,000 \mathrm{~m}^{2}$ of land and simple homes to 71 families. The movement hoped that such new approaches would facilitate advocacy efforts.

Villagers, with the support of their allies, attempted to improve solidarity and consolidate support. They established a shared identity, seeking to position residents as the developers' equals in the public eye. Through their campaign and advocacy activities, as covered in media publications, activists pressured the company to resolve the conflict. As part of new strategy, activists reduced their demand to 20 ha, a goal that they deemed more achievable. Their desired parcel of land was within Kualanamu Village, and held by PTPN II under cultivation rights ("Strategi Perjuangan KWML Menuju Relokasi \& Distribusi Lahan", August 2007).

As of the time of writing, residents have yet to achieve their desired results. When Kualanamu International Airport was inaugurated in 2013 , only a few residents had received compensation-a minimal amount of land, of unclear tenurial status, that was barely sufficient for building a house. Such compensation has been insufficient to reduce peri-urban villagers precarity in the face of aggressive urbanisation. Residents are still continuing their advocacy, seeking land with clear tenurial rights. As we will discuss below, the case of Kualanamu offers an important lesson for strengthening popular movements, promoting social justice, and creating rural-urban solidarity in Indonesia.

\section{Framing Problems and Conflicts within an Ecosoc Perspective}

"Human rights are premised on the notion of human dignity; human dignity requires that individuals be treated as autonomous beings, living in societies where they are recognized as persons of value, where they do not suffer from discriminatory legislation, where they are able to participate in collective decision-making, and where they can freely pursue their 
interests." (Howard-Hassman, 2000, p.

Economic, social, and cultural rights are ensconced within the International Covenant on Economic, Social and Cultural Rights (henceforth ICESCR), which was adopted by the United Nations General Assembly in 1966 together with the International Covenant on Civil and Political Rights. As of writing, 164 countries have ratified the ICESCR, including Indonesia, which ratified the covenant through Law No. 11 of 2005 regarding the Ratification of the International Covenant on Economic, Social and Cultural Rights.

Referring to these legal documents, the forced eviction of Pasar VI Kualanamu Village may be identified as a violation of residents' economic, social, and cultural rights. Such a finding was also made by the National Human Rights Commission (Komnas HAM RI) through letter 042a/R/Mediasi/VI/09, dated 29 June 2019. Similarly, residents' situation since the area was chosen for airport construction is also a violation of their human rights. Since 1997, villagers have been unable to fulfil their everyday needs, as they have been prohibited from using the land that they have traditionally cultivated.

Furthermore, the state has failed to recognise that its citizens were living in simplicity and harmony, without state facilitation. Likewise, the state has failed to respect that villagers were living independently, without disturbing or being disturbed by others. The state has failed to protect residents' land and their ability to survive without being hassled by others. Finally, the state has failed to fulfil citizens' need to be protected in a time of crisis and panic, as well as their need for farmland and food security.
For villagers and their allies, a rights approach was necessary for organisation. Furthermore, this rights approach offered a material basis for the mobilisation of a social movement. The state did not act as an abstract entity, but as a concrete institution that was manifested through specific actors whom residents had identified (see above). The movement thus sought to address 'state failures' from below. This approach was transformed into a specific strategy for improving political participation and achieving concrete goals through non-litigation means.

Nonetheless, private-sector actors prioritised the transformation of land into a profitable airport. Land is necessary for the operations of any business, and the building of a new airport-which served thousands of passengers every dayimplied the expansion of business interests. The price of land around the new airport skyrocketed, reaching hundreds of times its original value. In 2018, commercial developers began utilising the remainder of PTPN II's land to develop a service-based airport city, building hotels, hypermarkets, office buildings, a theme park, golf course, food arcade, convention centre, hospital, and cinema (Simorangkir, 2018). This bodes ill for the future of those living outside the airport walls is ominous, and a rights-based approach will remain relevant for residents of this peri-urban village.

\section{Conclusion: The Precarity of Resistance}

Persons who were evicted during the construction of the Kualanamu International Airport, as well as those living in the surrounding area, have faced diverse yet simultaneous structural problems. They have lost their access to land and their 
ability to cultivate necessary foodstuffs as the village has become increasingly urbanised. This disparity in development is rooted in the inequal social relations inherent to the plantation economy. The government, PT Angkasa Pura, and PTPN locked residents of Pasar VI Kualanamu Village in informal work relations that prevented retirees and their descendants from enjoying a good quality of life. Villagers' rights to land and a livelihood, recognised by the Convent on Economic, Social, and Cultural Rights and the Convent on Social and Political Rights, have been ignored. Villagers' de facto land and livelihoods have not been given de jure recognition, a situation common in periurban communities-i.e., amongst those whose traditional economy has been disrupted by the global processes of urbanisation and modernisation.

From a historical perspective, the plantation economy eroded traditional relations and created inequality; at the same time, the monoculture cultivation inherent to this system caused significant environmental degradation ( $\mathrm{Li}, 2010)$. Unprecedented urbanisation has exacerbated the situation, harming existing socio-economic relations while simultaneously creating new inequalities. At the same time, spatial organisation and land management systems have further marginalised villagers. Lacking ready access to income and livelihoods, villagers have limited capacity to consolidate themselves in resistance to state institutions' governance of land and space.

Many of Indonesia's social movements have faced similar obstacles, being forced to endure eviction after eviction as urbanisation has driven rapid economic and urban development. Reflecting on peri-urban communities' attempts to resist forced eviction and dispossession, we argue that it is necessary for social movements in diverse areas and sectors to create solidarity in their opposition to the continued pressures of development and urbanisation.

\section{References}

Akram-Lodhi, A.H., \& Kay, C. (2010a). Surveying the agrarian question (part 1): Unearthing foundations, exploring diversity. The Journal of Peasant Studies, 37(1), 177-202. https://doi.org/10.1080/03066150903498838.

Akram-Lodhi, A.H., \& Kay, C. (2010b). Surveying the agrarian question (part 2): Current debates and beyond. The Journal of Peasant Studies, 37(2), 255-284. https://doi.org/10.1080/03066151003594906.

Alexander, J., \& Alexander, P. (1991). Protecting peasants from capitalism: The subordination of Javanese traders by the colonial state. Comparative Studies in Society and History, 33(2), 370-394. https://doi.org/10.1017/S0010417500017060.

Aulia, E. W. (2006). Berjuta-juta dari Deli: Satoe hikajat koeli Contract. Gramedia Pustaka Utama.

Bakker, K., Kooy, M., Shofiani, N.E., \& Martijn, E-J. (2008). Governance failure: Rethinking the institutional dimensions of urban water supply to poor households. World Development, 36(10), 1891-1915. https://doi.org/10.1016/j.worlddev.2007.09.015.

Bhalla, S. (2017). From 'relative surplus population' and 'dual labour markets' to 'informal' and 'formal' employment and enterprises: Insights about causation and consequences. 
Agrarian South: Journal of Political Economy, 6(3), 295-305. https://doi.org/10.1177/2277976017745460.

Bitra Media Syndication (producer), \& Muhammad, H. (Director). (2007). Kualanamu, perjuangan menembus batas [Documentary].

Breman, J. (1997). Menjinakkan sang kuli: Politik kolonial pada awal abad ke-20. Pustaka Utama Grafiti.

Brenner, N., \& Schmid, C. (2014). The 'urban age' in question. International Journal of Urban and Regional Research, 38(3), 731-755. https://doi.org/10.1111/1468-2427.12115.

Byres, T. J. (2016). In pursuit of capitalist agrarian transition. Journal of Agrarian Change, 16(3), 432-451. https://doi.org/10.1111/joac. 12176.

Cuevas, S., Mina, C., Barcenas, M., \& Rosario, A. (2009). Informal employment in Indonesia. ADB Economics Working Paper Series No. 156, Manila: Asian Development Bank.

Elson, R. E. (1986). Sugar factory workers and the emergence of 'free labour' in nineteenthcentury Java. Modern Asian Studies, 20(1), 139-174. https://doi.org/10.1017/S0026749X00013615.

Grahadyarini, BM. L. (2013, April 12). Maju mundur Kualanamu. Kompas.com. https://ekonomi.kompas.com/read/2013/04/12/09233440/Maju.Mundur.Kualanamu.

Hadiz, V. R. (2004). Decentralization and democracy in Indonesia: A critique of neoinstitutionalist perspectives. Development and Change, 35(4), 697718. https://doi.org/10.1111/j.0012-155X.2004.00376.x.

Hadiz, V. R., \& Robison, R. (2005). Neo-liberal reforms and illiberal consolidations: The Indonesian paradox. The Journal of Development Studies, 41(2), 220-241. https://doi.org/10.1080/0022038042000309223.

Harvey, D. (2003). The new imperialism. Oxford University Press.

Harvey, D. (2012). Rebel cities: From the right to the city to the urban revolution. Verso.

Healey, P. (1999). Institutionalist analysis, communicative planning, and shaping places. Journal of Planning Education and Research, 19(2), 111-121. https://doi.org/10.1177/0739456X9901900201.

Hodgson, G. M. (2004). The evolution of institutional economics: Agency, structure, and Darwinism in American institutionalism. Routledge.

Jessop, B. (1996). State Theory: Putting the Capitalist State in Its Place. Polity Press and Blackwell Publishers.

Jessop, B. (2001). Institutional (re)turns and the strategic-relational approach. Environment and Planning, 33(7), 1213-1235. https://doi.org/10.1068/a32183.

Jessop, B. (2005). Critical realism and the strategic-relational approach. New formations: $A$ Journal of Culture, Theory and Politics, (56), 40-53.

Kaputra, I., Anto, J., \& Wahyudhi. (2015). Dari tembok Bandara Kualanamu, perjuangan warga Desa Pasar VI Kualanamu menuntut keadilan. Pustaka Sempu \& BITRA Indonesia. 
Kusbianto. (2016). Penyelesaian sengketa tanah perkebunan pada areal perusahaan badan usaha milik negara (BUMN) perkebunan di Sumatera Utara (Doctoral dissertation). Universitas Sumatera Utara, Medan, Indonesia.

Lambooy, J. G., \& Moulaert, F. (1996). The economic organization of cities: An institutional perspective. International Journal of Urban and Regional Research, 20(2), 217-237. https://doi.org/10.1111/j.1468-2427.1996.tb00312.x.

Leaf, M. (2002). A tale of two villages: Globalization and peri-urban change in China and Vietnam. Cities, 19(1), 23-31. https://doi.org/10.1016/S0264-2751(01)00043-9.

$\mathrm{Li}, \mathrm{T}$. M. (2010). To make live or let die? Rural dispossession and the protection of surplus populations. Antipode, 41(1), 66-93. https://doi.org/10.1111/j.14678330.2009.00717.x.

McMichael, P. (1997). Rethinking globalization: The agrarian question revisited. Review of International Political Economy, 4(4), 630-662. https://doi.org/10.1080/09672299708565786.

Mingione, E. (1991). Fragmented societies: A sociology of economic life beyond the market paradigm. Basil Blackwell.

Ministry of Villages, Development of Disadvantaged Regions, and Transmigration R. I (2015). Transmigrasi masa doeloe, kini dan harapan kedepan.

Moulaert, F., \& Mehmood, A. (2009). Spatial planning and institutional design: What can we expect from transaction cost economics? In H. S. Geyer (Ed.). International Handbook of Urban Policy Vol 2 (pp. 199-211). Edward Elgar Publishing.

Moulaert, F., Jessop, B., \& Mehmood, A. (2016). Agency, structure, institutions, discourse (ASID) in urban and regional development. International Journal of Urban Sciences, 20(2), 167-187. https://doi.org/10.1080/12265934.2016.1182054.

Narain, V. (2009). Growing city, shrinking hinterland: Land acquisition, transition and conflict in peri-urban Gurgaon, India. Environment \& Urbanization, 21(2), 501-512. https://doi.org/10.1177/0956247809339660.

Ostrom, E. (2005). Understanding institutional diversity. Princeton University Press.

Pembangungan bandar udara Kualanamu dimulai (2006, July 4). Ministry of Transportation Republic of Indonesia. http://dephub.go.id/post/read/PEMBANGUNAN-BANDARUDARA-KUALANAMU-DIMULAI746.

Rachman, N. F. (2012). Land reform dari masa ke masa. Tanah Air Beta \& Konsorsium Pembaharuan Agraria (KPA).

Reformulation of the Struggle Strategies of KWML towards Land Relocation and Distribution, prepared by the Coalition of Victims of the Kualanamu Airport Construction (Solidaritas untuk Rakyat Korban Pembangunan Bandara Kualanamu, SORAKKAN). (unpublished, 2007, August).

Rhoda, E. H. H. (2000). HAM: penjelajahan dalih relativisme budaya. Jakarta. Pustaka Utama Grafiti. 
Ruddick, S. (2015). Situating the anthropocene: Planetary urbanization and the anthropological machine. Urban Geography, 36(8), 1113-1130. https://doi.org/10.1080/02723638.2015.1071993.

Santoso, U. (2012). Hukum agraria: Kajian komprehensif. Kencana.

Schadee, W. H. M. (1919). Geschiedenis van Sumatra's oostkust, II. Oostkust van SumatraInstituut.

Sihaloho, Maratua (2004). Konversi Lahan Pertanian dan Perubahan Struktur Agraria (tesis Sekolah Pascasarjana). Institut Pertanian Bogor.

Simorangkir, E. (2018, February 3). 9 Investor Asia dan Eropa minati proyek bandara Kualanamu Rp. 11 T. Detik.com. https://finance.detik.com/infrastruktur/d-3848689/9-investorasia-dan-eropa-minati-proyek-bandara-kualanamu-rp-11-t.

Siyo, K., Soekirman, H., \& Purwadi. (2008). Wong Jowo di Sumatera: Sejarah, budaya, filosofi, dan interaksi sosial. Pujakesuma.

Stoler A. L. (1992) 'In cold blood': Hierarchies of credibility and the politics of colonial narratives. Representations, 37, 151-189. https://doi.org/10.2307/2928658.

Stoler, A. L. (1986). Plantation politics and protest on Sumatra's east coast. The Journal of Peasant Studies, 13(2), 124-143. https://doi.org/10.1080/03066158608438295.

Stoler, A. L. (1995). Capitalism and confrontation in Sumatra's plantation belt, 1870-1979. University of Michigan Press.

Swyngedouw E. (2004) Globalization or 'glocalization'? Networks, territories and rescaling. Cambridge Review of International Affairs, 17(1), 25-48. https://doi.org/10.1080/0955757042000203632.

van der Heijden, J. (2011). Institutional layering: A review of the use of the concept. Politics, 31(1), 9-18. https://doi.org/10.1111/j.1467-9256.2010.01397.x.

Watts, M. J. (1989). The agrarian question in Africa: Debating the crisis. Progress in Human Geography, 13(1), 1-41. https://doi.org/10.1177/030913258901300101. 